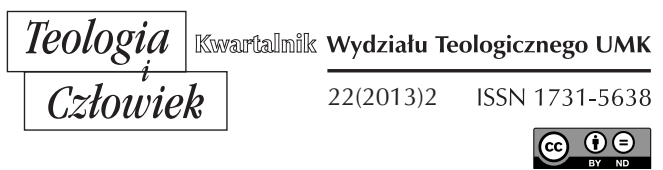

MIROSŁAW KUCZKOWSKI*

SIERAKOWICE

\title{
ARCYBRACTWO PASKA ŚW. FRANCISZKA Z ASYŻU W POLSCE NA PRZESTRZENI WIEKÓW
}

DOI: http://dx.doi.org/10.12775/TiCz.2013.016

\section{WSTĘP}

Człowiek wierzący dąży do zbawienia, które można osiągnąć, idąc różnymi drogami. Jedną $\mathrm{z}$ nich było zrzeszanie się $\mathrm{w}$ bractwach kościelnych ${ }^{1}$, pomocnych $\mathrm{w}$ osiągnięciu tego celu. Wspólnoty $\mathrm{w}$ historii określane były różnymi nazwami, najbardziej znanymi to bractwo - confraternitas, a także: confratria, confraria, confratica, fratria, frateria, geldonia (gilda), sodalitas, congregatio, societas (towarzystwo), coetus (związek), foedus (przymierze, stowarzyszenie, zjednoczenie), liga spiritualis (liga duchowna) $)^{2}$.

* Mirosław Marek Kuczkowski jest doktorem nauk teologicznych w zakresie historii Kościoła. Jest świeckim franciszkaninem.

${ }^{1}$ Bractwa kościelne, w: Encyklopedia chrześcijaństwa, Kielce 2000, s. 116: „To zrzeszenia świeckich, które powstały w środowisku chrześcijańskim dla dokonywania dzieł miłości, pobożności i pokuty, ale bez warunku składania szczególnych ślubów i prowadzenia życia wspólnotowego".

${ }^{2}$ K. Kuźmak, Bractwo kościelne, w: Encyklopedia katolicka, t. II, Lublin 1995, kol. 1013. 
Poprzez przynależność do konfraterni osoby wierzące rozwijały swoje życie duchowe, a także budowały nowy typ pobożności ludowej. Do bractw religijnych przyjmowano na zasadzie dobrowolności, nie określano stanu posiadania, pochodzenia, czy też innych warunków społeczno-ekonomicznych koniecznych, aby przystąpić do wspólnoty. Jedynym kryterium była wola osiągnięcia łaski nieba, która tworzyła więź wspólnoty brackiej wyrażanej poprzez braterską modlitwę oraz możliwość uzyskania dodatkowych odpustów, a także troskę o ubogich. Ponadto opiekowano się powierzonymi kaplicami, ołtarzami i feretronami (obrazami), co miało wpływ na aktywność ludzi świeckich w parafiach.

Postać św. Franciszka z Asyżu inspirowała ludzi różnych epok, kultur i religii. Jego osoba zachwycała poetów i „zwykłych" ludzi, a ideały ewangelicznego radykalizmu stały się podstawą nurtu franciszkańskiego w duchowości chrześcijańskiej. Franciszkowe idee realizowały osoby konsekrowane $^{3}$ i świeckie ${ }^{4}$, a także członkowie bractw opierających się na duchowości franciszkańskiej, a mianowicie: Pokutnicze Bractwo Stygmatów św. Franciszka, a także Arcybractwo Paska św. Franciszka ${ }^{5}$ i Bractwo Paska św. Antoniego ${ }^{6}$.

\section{O BRACTWACH W OGÓLNOŚCl}

\subsection{BRACTWA NA PRZESTRZENI WIEKÓW}

Poszukując źródeł ruchów brackich, nie można bagatelizować poglądu o tworzeniu się ich już w IV wieku po edykcie mediolańskim ${ }^{7}$.

${ }^{3}$ Zakony św. Franciszka w Polsce w latach 1772-1970, red. J. Bar, t. 1, Warszawa 1978: w tym wydaniu został zaprezentowany drugi zakon i trzeci regularny (zgromadzenia męskie, zakony klauzurowe, zgromadzenia habitowe powstałe na ziemiach polskich i przybyłe z zagranicy, zgromadzenia bezhabitowe powstałe na ziemiach polskich) oraz Zakony św. Franciszka w Polsce w latach 1772-1970, red. J. Bar, t. 2, Warszawa 1978: część druga poświęcona jest braciom mniejszym kapucynom i konwentualnym.

${ }^{4}$ J. Bar, Tercjarstwo franciszkańskie, Kraków 1945, s. 18-20, a także M. Kuczkowski, Dzieje Trzeciego Zakonu św. Franciszka z Asyżu na ziemiach polskich w latach 1918-1939 w świetle czasopism tercjarskich, Pelplin 2010, s. 32-41 oraz Historya Tercyarstwa. O zatożeniu Trzech Zakonów, w: Nowy Brewiarzyk Tercyarski, Kraków 1919, s. 35-38.

${ }^{5}$ K. Kuźmak, Bractwo kościelne, kol. 1019.

${ }^{6}$ Zakony św. Franciszka w Polsce w latach 1772-1970, s. 46.

7 J. Wiśniewski, Pomezańskie bractwa religijne, Olsztyn 2007, s. 6, a także A. Weiss, Konfraternie kaptańskie w XVIII-wiecznej Polsce, w: Kościót w Polsce. Dzieje i kultura, red. J. Walkusz, t. II, Lublin 2003, s. 7. 
Ruchy brackie mogły być grupami, które stawały wobec unifikacji życia kościelnego, a także były organizacjami wiernych, które „lepiej” realizowały rady ewangeliczne.

Historycy zajmujący się badaniem początków bractw religijnych dopatrują się ich początków w stowarzyszeniach modlitewnych tworzonych przez św. Bedę Czcigodnego (†735) i św. Bonifacego (†754) $)^{8}$.

W VII wieku powstawały bractwa klasztorne, których jednym z zadań była wzajemna modlitwa zakonników ${ }^{9}$, także część duchowieństwa diecezjalnego organizowała się w bractwa kapłańskie zobowiązujące się do modlitwy za zmarłych duchownych i odprawiania Mszy św. za żyjących, a także opieki socjalnej ${ }^{10}$.

W XII wieku znane były stowarzyszenia religijne ludzi świeckich tworzonych przy klasztorach, gdzie szukano bezpieczeństwa dla swoich rodzin, a także ideałów życia pokutnego ${ }^{11}$. Bractwa ożywiały i pogłębiały życie religijne w parafiach, a także odgrywały w środowiskach społecznych ważną rolę. Niektórzy z wiernych należeli nawet do kilku bractw.

W czasach nowożytnych różne prądy reformacyjne starały się wprowadzić zamęt w naukę Kościoła. Odpowiedzią była mobilizacja w szeregach bractw religijnych gorliwych katolików, którzy jeszcze bardziej dbali o pobożność i wierność Kościołowi wobec ruchów protestanckich. W związku z tym, formowały się liczne bractwa różnego typu ${ }^{12}$,

${ }^{8}$ W. Bochniak, Religijne stowarzyszenia $i$ bractwa katolików świeckich $w$ diecezji wroctawskiej od XVI wieku do 1818 roku, Legnica 2000, s. 48-49.

9 Tamże: „Praktykę wzajemnej modlitwy mnichów, tę prawdziwą confraternitas zakonników, wypracowały klasztory benedyktyńskie. Ta wzajemna modlitwa prowadziła do swoistego przymierza pokoju między zakonami w czasie sporów o zasadność ideału i sposób prezentacji nauki Kościoła. Te fakty potwierdzały, istniejące już w 622 r. na terenie Francji, księgi zmarłych, w których zapisywano umierających mnichów w różnych domach klasztornych, w różnych zakonach, tak męskich jak żeńskich. Tak powstały dobrze zorganizowane bractwa klasztorne, których członkowie zawierali porozumienia o wzajemnej modlitwie, będące doskonałym wzorem dla bractw religijnych dla ludzi świeckich".

${ }^{10}$ A. Weiss, Konfraternie kaptańskie, s. 8-14.

11 A. Morichetti, Historia Franciszkańskiego Zakonu Świeckich, w: Budowanie braterstwa ze świętym Franciszkiem, Kraków 1993, s. 69: „Ruch pokutujących istniejący przed Franciszkiem znajduje swój początek w starodawnych systemach Kościoła. Byli wówczas wierzący świeccy, którzy spragnieni wyższej doskonałości, przyjmowali dobrowolnie pokutę kanoniczną, pozostając w świecie, we własnych domach, przy spełnianiu swoich codziennych obowiązków".

${ }^{12}$ J. Wiśniewski, Pomezańskie bractwa, s. 8: „Wówczas powstały bractwa szerzące cześć Najświętszego Sakramentu, Najświętszej Marii Panny, świętych, a także bractwa 
między innymi Ignacy Loyola założył Bractwo Dwunastu Apostołów (1564) zatwierdzone przez Piusa IV (1559-1565), które później papież Sykstus V (1585-1590) podniósł do rangi arcybractwa. W 1566 roku w Rzymie przy kościele S. Agostino założono Bractwo Drukarzy p.w. Czterech ŚŚ. Doktorów Kościoła (Ambrożego, Augustyna, Hieronima i Grzegorza Wielkiego), które w 1600 roku połączyło się z Bractwem Księgarzy promującym dobre książki. Innym bractwem działającym w całym Kościele było Bractwo Miłosierdzia, obdarzone przez papieża licznymi odpustami. W Polsce propagowane było ono przez ks. Piotra Skargę (1536-1612), a jednym z zadań bractwa było wspomaganie ubogich ${ }^{13}$.

Bractwa religijne w XIII wieku miały niezależność, co niepokoiło hierarchię kościelną. Kościół jedynie dokonywał erygowania wspólnot, które kierowały się swoimi zasadami ujętymi w statuty. Członkowie bractw byli zobowiązani do przestrzegania przepisów, które jednak nie obowiązywały pod karą grzechu. Niektóre z nich zwracały się do księży diecezjalnych lub kapłanów zakonnych wyłącznie o sprawowanie Mszy św. i wygłoszenie kazania w czasie spotkań brackich. Bractw nie można było utożsamiać z korporacjami zawodowymi, choć były one podobne w swojej wewnętrznej strukturze organizacyjnej, a także realizowały cele dewocyjne $e^{14}$.

W 1584 roku papież Grzegorz XIII (1572-1585) w konstytucji Omnipotentis Dei dał niektórym zakonom przywilej wyłączności nad niektórymi bractwami. Jezuici otrzymali prawo zakładania i wizytowania sodalicji mariańskich, a w 1586 roku prawo egzempcji nad bractwami prowadzonymi przez to zgromadzenie. Dominikanie otrzymali przywilej jurysdykcji nad wspólnotami różańcowymi, a karmelici nad szkaplerznymi.

$\mathrm{Z}$ upływem lat zostały wypracowane stosowne przepisy prawne dla bractw i stowarzyszeń religijnych, a mianowicie „papież Klemens VII

pokutne. Natomiast członkowie bractw rycerskich, mające na celu walkę z heretykami, składali przysięgę wierności i posłuszeństwa przełożonym Kościoła: papieżowi, biskupowi, przełożonym bractwa i dowódcom wojskowym".

${ }^{13}$ M. Banaszak, Historia Kościota Katolickiego, t. 3, Warszawa 1989, s. 199.

${ }_{14}$ J. Wiśniewski, Pomezańskie bractwa, s. 9: „Tymczasem cechy, ponieważ nie były powołane $\mathrm{w}$ taki sposób, zawierały specjalne umowy z proboszczem lub przełożonym klasztoru o posłudze kapłańskiej członkom cechu, wynagradzając za tę czynność. W razie jednak naruszenia umowy przez księży cech mógł przenieść się do innej świątyni, zawierając kolejną umowę z nowym duchownym. Takiego prawa nie miały bractwa religijne, które aktem erekcyjnym zostały na stałe związane z duchowieństwem obsługującym kościół, przy którym zostało powołane". 
publikując dnia 7 grudnia 1604 roku konstytucję Quaecumque a Sede Apostolica, ustanowił ostatecznie strukturę i zasady działania każdego bractwa"15. Na Soborze Trydenckim postanowiono, że bractwa będą podlegały ustawodawstwu synodalnemu i nadzorowi biskupów miejsca ${ }^{16}$.

W XVIII wieku biskupi otrzymali prawo wizytowania kaplic i ołtarzy bractw założonych przy klasztorach, a także mieli prawo ingerowania w ich nabożeństwa i mogli zezwalać na wystawienie Najświętszego Sakramentu w uroczystości brackie. Wspólnoty występowały na nabożeństwach i w procesjach parafialnych z własnym sztandarem, godłem (znakiem), a także miały prawo do noszenia stosownych szat brackich. O zajmowaniu miejsca (precedencji) podczas procesji decydował czas założenia bractwa, najstarsze $\mathrm{z}$ nich postępowało przed duchowieństwem ${ }^{17}$.

Znaczący kryzys w bractwach nastąpił w drugiej połowie XVIII wieku wskutek przemian społecznych i politycznych, we Francji i Italii zlikwidowano je ustawami rządowymi, a w zaborze austriackim dekretem Józefa II. Przy niektórych parafiach pozostały bractwa nieoficjalnie, lecz niestety była to tylko mierna egzystencja bez właściwego kierownictwa. Wcześniej w miejscowościach, gdzie nastąpiła zmiana wyznania katolickiego na protestanckie, następował także zanik bractw kościelnych. Dotychczas pełniona przez nich posługa dotycząca dzieł charytatywnych, opieki społecznej i życia religijnego została przejęta przez Rady Miasta, tym samym eliminując podstawowe cele bractw. Dopiero w XIX i XX wieku nastąpiło ponowne odrodzenie ruchu brackiego.

\subsection{BRACTWA W POLSCE}

Najstarsze bractwa w Polsce znajdowały się w Środzie Śląskiej (1245), Ziębicach (1250) i w Bolkowicach (1298), zajmowały się one pielęgnacją chorych, prowadzeniem przytułków dla żebraków i bezdomnych (bractwa szpitalne).

15 Tamże, s. 15.

16 K. Kuźmak, Bractwo kościelne, kol. 1015: „Sobór Tryd. (ses. XXII c. VIII-IX), uznając b. za osobę mor., poddał je bezpośredniej jurysdykcji Stolicy Apost. i ordynariuszy miejsca. Normy ogólne Soboru skonkretyzowane zostały w zarządzeniach papieży i odpowiednich kongregacji rzym. (Kongr. Soboru, Bpów, Zakonów, Odpustów, Obrzędów). Konstytucja Quaecunque pap. Klemensa VIII z 7 XII 1604, której postanowienia zachowały moc do dzisiaj, ustaliła warunki prawnej egzystencji b. oraz podstawowe zasady ich życia i działalności".

17 J. Wiśniewski, Pomezańskie bractwa, s. 16. 
Na przestrzeni XI-XII wieku rozwijały się bractwa związane z rozwojem kultu Bożego Ciała, a pod koniec XIII wieku bractwa eucharystyczne. Intensywny rozwój tego ruchu nastąpił od XIV wieku, wtedy powstały bractwa: maryjne, literackie, patronów świętych, szkaplerza św., bractwo ubogich, Najświętszego Sakramentu. Najbardziej powszechne były bractwa maryjne, które znajdowały się $\mathrm{w}$ większości parafii ${ }^{18}$.

W XV wieku działały bractwa różańcowe, Świętego Ducha zajmujące się opieką chorych oraz bractwa św. Bernarda ${ }^{19}$.

W okresie reformacji nastąpiły liczne odstępstwa od Kościoła katolickiego, proces ten dotkną także bractw kościelnych. Powolne ich odradzanie następowało dopiero pod koniec XVI wieku, gdzie znaczącą rolę odegrały zgromadzenia zakonne. Do końca XVIII wieku powstało wiele bractw, m.in. św. Benona i św. Rocha ${ }^{20}$. W tym czasie, w około $40 \%$ parafiach wiejskich istniały konfraternie.

Niestety, okres zaborów doprowadził do kasaty zakonów, a także wielu bractw. Do przodujących w tej dziedzinie należał zabór austriac$\mathrm{ki}^{21}$. Biskup przemyski Józef Kierski (1768-1783), popierający bractwa religijne "został zmuszony przez zaborcze władze austriackie do kasaty (w 1782 r.) bractwa Pocieszenia N.M. Panny, bractwa Serca Jezusowego oraz bractwa św. Franciszka. Zaborca uzasadniał, że powyższe bractwa zostały założone $\mathrm{z}$ chęci zysku materialnego, a nie pobożności"22.

Od połowy XIX wieku nastąpiło odrodzenie konfraterni, zakładano nowe bractwa kultowo-charytatywne, religijno-oświatowe, trzeźwościowe. Niejednokrotnie $\mathrm{z}$ bractw powstawały zgromadzenia zakonne, które w swoich nazwach i praktykach religijnych zapożyczały elementy $\mathrm{z}$ bractw $^{23}$.

18 Tamże, s. 18, a także K. Kuźmak, Bractwo kościelne, kol. 1016-1020.

${ }_{19}$ B. Kumor, Sytuacja Kościoła w Polsce na początku XVI wieku, w: Historia Kościoła w Polsce, t. 1, cz. 2: (1506-1764), red. B. Kumor, Z. Obertyński, Poznań-Warszawa 1974, s. 22.

${ }^{20}$ J. Mandziuk, Historia Kościota katolickiego na Śląsku. Czasy reformacji protestanckiej, reformy katolickiej i kontrreformacji 1520-1742, t. 2, Warszawa 1995, s. 98-99.

${ }^{21}$ A. Sroka, Prowincja M.B. Bolesnej w Galicji (1815-1899), w: Zakony św. Franciszka w Polsce w latach 1772-1970, s. 205: „Działalność wszelkich bractw w państwie austriackim była zabroniona".

${ }^{22}$ J. Wiśniewski, Pomezańskie bractwa religijne, Olsztyn 2007, s. 19.

${ }^{23}$ K. Kuźmak, Bractwo kościelne, kol. 1015. 


\section{O ARCYBRACTWACH W OGÓLNOŚCI}

Arcybractwo (archikonfraternia) jest bractwem kościelnym wyróżnionym przez Stolicę Apostolską godnością, przywilejami i odpustami, a także posiada uprawnienia agregacji (łączenia) bractw tej samej nazwy, i takich samych celów. Niektóre z bractw otrzymują tytuł honorowy bez uprawnień $\mathrm{w}$ odniesieniu do innych wspólnot. Arcybractwo nie różni się w stosunku do bractw, co do natury, zasadniczych funkcji i struktur.

Początek arcybractw przypada na XVII wiek i związany był z potrzebą uporządkowania struktury organizacyjnej licznie powstałych bractw w czasach kontreformacji, a także ujednolicenia i ożywienia działalności. Na przestrzeni pięciu wieków powstało ponad sto arcybractw.

Podstawowe przepisy prawne odnoszące się do stowarzyszenia zostały ustanowione przez papieża Klemensa VIII, a następnie przez kolejnych papieży, a także zostały ujęte $\mathrm{w}$ dekretach soborowych oraz w dokumentach Kongregacji Obrzędów i Odpustów. Ostatecznie uporządkowania i systematyzacji prawodawstwa dokonano w Kodeksie Prawa Kanonicznego $0^{24}$.

Prawo kościelne z 1917 roku rozróżniało trzy rodzaje zrzeszeń religijnych, do których mogły należeć osoby świeckie, a mianowicie: trzecie zakony (dominikański, franciszkański, karmelitański), pobożne stowarzyszenia i bractwa. Podstawą tego podziału był cel i organizacja obrany przez zrzeszenie.

W skład trzecich zakonów wchodzą osoby świeckie, które starają się dążyć do chrześcijańskiej doskonałości pod kierunkiem i według duchowości wybranego zakonu zgodnie z jego regułą w świeckim stanie ${ }^{25}$.

Pobożne stowarzyszenia są związkiem wiernych, które obierają sobie za cel wypełnianie dzieł pobożności i miłości chrześcijańskiej (np. wspomaganie misji, utrzymywanie ochronek, sierocińców itp.). Jeśli takie stowarzyszenie zostało kanonicznie erygowane nazywało się sodalicją. Sodalicja zgodnie z wymogami posiadała swój zarząd $\mathrm{d}^{26}$.

24 K. Kuźmak, Arcybractwo, w: Encyklopedia katolicka, t. I, Lublin 1995, kol. 891-894.

25 Codex Iuris Canonici, Vaticana 1931, s. 209: „Can. 702. - §I. Tertiari saeculares sunt qui in saeculo, sub moderatione alicuius Ordinis, secundum eiusdem spiritus, ad christianam perfectionem contendere nituntur, modo saeculari Vita consentaneo, secundum regulas ab Apostolica Sede pro ipsis approbatas".

26 Tamże, s. 210: Can. 708. 
Bractwa (sodalicje), czyli pobożne stowarzyszenia zorganizowane kanonicznie, w których oprócz dzieł chrześcijańskiego miłosierdzia, uświetniano publiczny kult (nabożeństwa). Jeśli bractwo posiadało specjalny przywilej przyłączanie do siebie innych bractw tego samego rodzaju, to nazywało się arcybractwem ${ }^{27}$.

\section{ARCYBRACTWO PASKA ŚW. FRANCISZKA Z ASYŻU}

\subsection{POCZAZTKI ARCYBRACTWA}

Arcybractwo Paska zostało założone w bazylice asyskiej i zatwierdzone przez papieża Sykstusa V (1585-1590) w konstytucji apostolskiej Ex supernae Dispositionis z 19 listopada 1585 roku $^{28}$. W dokumencie erekcyjnym bractwa papież tak napisał: „Gdy św. Franciszek tak żył, że prawie wszystkich pociągał za sobą, i wielu wiernych nosi dziś jeszcze powróz, którym się on opasywał, dlatego My, którzy od najmłodszych lat odznaczali się szczególniejszym nabożeństwem do św. Franciszka i przywdziali habit w jego zakonie, pragnąc jak najwięcej ozdobić jego grób i kościół oraz wszędzie rozszerzyć praktyki pobożności i chrześcijańskiej miłości przy równoczesnym rozszerzaniu czci bożej, z własnego natchnienia a nie na czyjeś prośby, powaga apostolską niniejszego pisma zakładamy po wieczne czasy w kościele św. grobu przy ołtarzu wielkim tejże bazyliki - arcybractwo dla wiernych obojga płci, których obowiązkiem właściwym jest nosić pasek, jaki noszą bracia tego zakonu i nim się przepasywać" 29 .

27 Tamże, s. 213: Can. 720.

${ }^{28}$ Arcybractwo Paska św. Franciszka, „Pochodnia Seraficka”, 7 (1935), s. 220: „papież Pius V [winno być Sykstus V] konstytucją ",ex Supernak dispositionis” z dnia 19 listopada 1585 r. erygował i zatwierdził przy bazylice asyskiej Braci Mniejszych konwentualnych Arcybractwo Paska św. Franciszka. Odtąd Stowarzyszenie szybko rozprzestrzeniać się poczęło w całym świecie katolickim", a także .Arcybractwo Paska św. Franciszka, „Pochodnia Seraficka”, 12 (1935), s. 380: „Do lipcowego numeru wkradł się błąd drukarski, mianowicie założycielem arcybractwa paska był nie Pius $\mathrm{V}$, ale Sykstus V (1585-1590). Słynny ten papież pochodził spod Ankony, dokąd przeniosła się jego słowiańska rodzina Perettich. Jako 9-letni chłopiec wstąpił do franciszkanów. Niezwykłe zdolności zapewniły mu wielką przyszłość początkowo w zakonie, a potem w Kościele” oraz Arcybractwo Paska św. Franciszka, „Pochodnia Seraficka” 1 (1936), s. 29.

${ }^{29}$ Arcybractwo Paska św. Franciszka, „Pochodnia Seraficka” 1 (1936), s. 28. 
Następnie papież udzielił generałom zakonu Braci Mniejszych władzy zakładania podobnych stowarzyszeń na całym świecie i wcielania ich (agregowania) do arcybractwa asyskiego. Przywilej ten został potwierdzony przez papieży Pawła V (1605-1621) w konstytucji apostolskiej Nuper Archiconfraternitati z 11 marca 1607 roku $^{30}$ i papieża Klemensa X (1670-1676) w Dudum felicis ${ }^{31}$.

Papież Pius XI w encyklice Rite expiatis zachęcał wiernych, którzy nie mogli z pewnych przeszkód należeć do Trzeciego Zakonu, aby wpisywali się do Arcybractwa Paska św. Franciszka ${ }^{32}$.

W Polsce arcybractwo szybko się rozpowszechniało. Już w 1597 roku przetłumaczono i wydrukowano przywileje i odpusty brackie. W 1603 roku nuncjusz papieski Klaudiusz Rangoni (1598-1607) zezwolił na organizowanie procesji z Najświętszym Sakramentem przy wszystkich kościołach, gdzie założone było arcybractwo. W 1906 roku ukazała się książka pt. Bractwo chordy albo paska zakonu św. Franciszka ${ }^{33}$.

\subsection{SYMBOLIKA PASKA}

Pasek stał się symbolem przypominającym św. Franciszka ${ }^{34}$ i oznaką przynależności do wielkiej rodziny franciszkańskiej, a także symbolem czystości obyczajów i pokuty. Miał również przypominać o „,wznoszeniu” duszy ku Bogu ${ }^{35}$.

\footnotetext{
${ }^{30}$ Tamże.

31 Tamże, s. 29.
}

${ }^{32}$ J. Bar, Z. Włodarczyk, w: Św. Franciszek i Asyżu i jego trzeci zakon, WrocławKraków 1948, s. 57: „Niech w tym roku wszyscy na skutek Waszej zachęty zaciągną się pod sztandar tego sławnego rycerstwa; ci zaś, którzy z powodu swego wieku uczynić tego jeszcze nie mogą, niech jako kandydaci zapiszą się do paska św. Franciszka".

${ }^{33}$ Tamże.

${ }^{34}$ Arcybractwo Paska św. Franciszka, „Wiadomości Tercjarskie” 28 (1936), s. 107: „Franciszek otrzymał to, o co prosił w dalekiej perspektywie szlak przyszłego życia. A że $\mathrm{u}$ niego czyn następował natychmiast po postanowieniu, bezzwłocznie więc odwiązał rzemyki od obuwia, porzucił kij podróżny, sakiewkę, pieniądze i rzemień do opasywania bioder, a pozostawszy w jednej ubogiej opończy, spiął ją w pasie powrozem".

${ }^{35}$ Arcybractwo Paska św. Franciszka, „Pochodnia Seraficka” 12 (1935), s. 379: „Myśl tę pięknie wyraża kapłan, gdy przy opasywaniu kandydata świętym paskiem napomina: „Weźmij ten pasek na twoje biodra, aby one były przepasane na znak umartwienia i czystości". Jak powłóczystą szatę ściągamy paskiem, iżby się po ziemi nie wlokła, tak i duszę powściągać trzeba, aby się uczucia jej w ziemi nie kalały. A trudna to rzecz, 
Specjalną wymowę miały trzy supły paska, które oznaczały trzy węzły duchowe łączące ludzi z Bogiem, a mianowicie: „węzeł natury, łaski i chwały; oraz przypominają nasz potrójny obowiązek względem Boga, bliźnich i siebie"36.

\subsection{SPOSÓB ZAKŁADANIA ARCYBRACTWA}

Zgodnie z prawem kościelnym erygowanie stowarzyszeń kościelnych należało do Stolicy Apostolskiej ${ }^{37}$ i biskupa miejsca ${ }^{38}$. W przypadku ordynariusza władza dotycząca erygowania niektórych stowarzyszeń była ograniczona ze względu na specjalny przywilej dany zakonom przez papieża odnoszący się do tworzenia nowych bractw.

Jednym ze stowarzyszeń zarezerwowanych zakonowi Braci Mniejszych Konwentualnych (franciszkanów) należy wspomniane arcybractwo Paska św. Franciszka. Generał zakonu mógł na mocy udzielonego przywileju erygować arcybractwo we wszystkich kościołach, kaplicach publicznych i kaplicach półpublicznych. Do erygowania wymagana jednak była zgoda biskupa miejsca.

W przypadku zakładania arcybractwa niezorganizowanego ${ }^{39}$ przy kościołach klasztornych (franciszkanów konwentualnych) nie było konieczne nowe pozwolenie biskupa lecz wystarczało to, które zezwalało na założenie klasztoru. Jednak do erygowania stowarzyszenia posiadającego własny zarząd, wymagana była zgoda ordynariusza na piśmie.

W kościołach kleru diecezjalnego niezależnie od formy organizacji arcybractwa zawsze wymagana była pisemna zgoda biskupa diecezjalne$\mathrm{go}^{40}$. Władzę erygowania arcybractwa paska św. Franciszka, oprócz generała zakonu Braci Mniejszych Konwentualnych, posiadali także generałowie innych obediencji franciszkańskich, ale tylko w kościołach i miejscowościach, gdzie nie ma franciszkanów konwentualnych, ani tego założonego

pasek więc przypomina, że Bóg przez zasługi Patrjarchy Franciszka skutecznie pomaga swą łaską do pokonania namiętności ciała i otrzymania cnoty wstrzemięźliwości".

${ }^{36}$ Arcybractwo Paska św. Franciszka, „Wiadomości Tercjarskie” 28 (1936), s. 109.

${ }^{37}$ Codex, s. 65-68: Sprawy stowarzyszeń (bractw) prowadzone były przez Kongregację Soborową (Can. 250. §2) i Kongregację Rozkrzewiania Wiary (Can. 252) dla krajów misyjnych.

${ }^{38}$ Tamże, s. 204: Can. 686.

${ }^{39}$ Nieposiadającego własnego zarządu.

${ }^{40}$ Codex, s. 204: Can. 686. §3. 
arcybractwa. Ten przywilej został nadany przez papieża Sykstusa V w konstytucji Divinae Charitatis, a także potwierdzony przez papieży Pawła V i Klemensa X we wspomnianych konstytucjach apostolskich ${ }^{41}$.

Kanonicznego erygowania arcybractwa paska św. Franciszka dokonywał generał zakonu, urzędowym dekretem dającym bractwu osobowość prawną, prawo trwałości, prawo nabywania, posiadania i zarządzania majątkiem oraz prawo stawania przed sądem kościelnym. Na mocy uzyskanych praw członkowie korzystali z łask i przywilejów duchowych ${ }^{42}$.

Dekret erekcyjny musiał być przechowywany w archiwum kościelnym, a także mógł być umieszczany przy ołtarzu brackim. Za wydanie dekretu nie można było żądać żadnych opłat z wyjątkiem zwrotu kosztów kancelaryjnych.

Inicjatywa założenia arcybractwa w kościołach klasztornych należała do przełożonych zakonnych, a w kościołach parafialnych do proboszczów. Proces tworzenia nowego bractwa odbywał się w podobny sposób, otóż wybierano najczęściej kilku chętnych mężczyzn, którzy mogli zająć określone miejsce w kierownictwie bractwa. Następnie byli oni informowani o celach i założeniach stowarzyszenia. Jeżeli chętni wyrażali zgodę, to zwracano się o stosowne pozwolenia do biskupa miejsca i generała zakonu. Po otrzymaniu zgody ogłaszano z ambony informację o możliwości przystąpienia do arcybractwa, a także objaśniano zasady działania i zachęcano do, jak najliczniejszego wstępowania w szeregi. Założenie arcybractwa było obchodzone bardzo uroczyście, z okolicznościowym kazaniem i Komunią św.

Po ustanowieniu bractwa, dyrektor przyjmował i wpisywał członków do specjalnej księgi brackiej” ${ }^{43}$, a następnie „wręczając im, a raczej opasując paskiem pobłogosławionym przez przełożonych franciszkańskich - np. gwardjana lub prowincjała (konst. Ex Supernae Dispositionis; Nuper archiconfraternitati, § 1; Dudum felicis)"44 dopełniał obrzędu przyjęcia. Wręczenie paska mogło się odbywać uroczyście podczas nabożeństwa przy brackim ołtarzu.

\footnotetext{
${ }^{41}$ Arcybractwo Paska św. Franciszka, „Pochodnia Seraficka” 1 (1936), s. 30.

${ }^{42}$ Arcybractwo Paska św. Franciszka, „Wiadomości Tercjarskie” 28 (1936), s. 112, a także Codex (Can. 102, Can. 1495. §2, Can. 1557. §2: n. 2, Can. 1649.).

43 Tamże, Can. 694. §2.

${ }^{44}$ Arcybractwo Paska św. Franciszka, „Pochodnia Seraficka” 1 (1936), s. 30, a także Arcybractwo Paska św. Franciszka, „Wiadomości Tercjarskie” 28 (1936), s. 113.
} 


\subsection{CZłONKOWIE}

Członkami arcybractwa mogli być wierni świeccy, którzy nie posiadali przeszkód kanonicznych. Jednak, aby zostać członkiem bractwa należało zgłosić się do kapłana mającego władzę przyjmowania i złożyć stosowną prośbę o przyjęcie. Przyjęcia dokonywał dyrektor przez wpisanie do księgi brackiej i wręczenie paska ${ }^{45}$. Złożenie prośby nie było wymagane na piśmie, wystarczyło ustnie wyrazić chęć wstąpienia do bractwa i zadeklarować wypełnianie statutów stowarzyszenia. Wpisywać się mogli mężczyźni, kobiety i dzieci. W przypadku kobiet występowały pewne ograniczenia, a mianowicie nie mogły sprawować żadnych funkcji, ani też wybierać zarządu i uczestniczyć w urzędowych posiedzeniach brackich (Can. 709. §1). Dzieci nie mogły być przyjmowane przed dojściem do „używania" rozumu, co w praktyce przekładało się na czas po Pierwszej Komunii św. Zgodę na wstąpienie do bractwa w przypadku dzieci wyrażali rodzice lub ich opiekunowie. Za przynależność i wstąpienie do bractwa nie pobierano opłat. Jedynie po podjęciu uchwały przez członków można było ustalić dobrowolna składkę miesięczną na upiększenie kościoła, a w szczególności ołtarza brackiego.

Dyrektor przyjmował do bractwa poprzez wpis do księgi członkowskiej i wręczenie oraz opasanie kandydatka paskiem św. Franciszka. W miejscowościach, gdzie nie było arcybractwa chętni, którzy chcieli korzystać z odpustów i łask przypisanych do stowarzyszenia, mogli zgłaszać się do oo. franciszkanów konwentualnych, aby otrzymać pasek i korzystać z "dobrodziejstw" stowarzyszenia.

\subsection{OBOWIAZKKI}

Zasadniczym obowiązkiem było noszenie paska ${ }^{46}$, który warunkował korzystanie z przywilejów i odpustów nadanych przez Stolicę Apostolską. Członek nienoszący paska nie tracił przynależności, lecz nie mógł dostępować łask przypisanych stowarzyszeniu.

Paskiem należało być opasanym wokół bioder, nie można go było nosić $\mathrm{w}$ kieszeni, czy też $\mathrm{w}$ innej części garderoby. Zdjęcie paska

${ }^{45}$ Codex, s. 145: Can. 694. \$2.

46 Arcybractwo Paska św. Franciszka, „Wiadomości Tercjarskie” 28 (1936), s. 115: „Pasek bracki pod względem wyglądu ma być podobny temu, jaki noszą bracia mniejsi konwentualni". 
z powodu słusznej przyczyny (kąpiel, wizyta u lekarza, sen itp.) nie powodowało utraty przywilejów. Przed pierwszym wręczeniem paska, był on błogosławiony ${ }^{47}$, a wszystkie kolejne paski nie musiały być ponownie błogosławione.

Członkom zalecano również, aby codziennie w swojej praktyce religijnej podejmowali „rozmyślania i odmawiania 6 Ojcze nasz, 6 Zdrowaś i 6 Chwała Ojcu, na cześć ran Chrystusowych i stygmatów św. O. Franciszka. Zachęca się także wszystkich członków do uczestniczenia w nabożeństwach i procesjach brackich, do brania udziału w konferencjach głoszonych przez dyrektora"48. Zaniedbanie któregokolwiek z obowiązków brackich nie było objęte karą grzechu. Dostosowanie się do określonych warunków wynikało z pobożności poszczególnych członków. Na dyrektorze spoczywał obowiązek rozpoznania kandydata pod względem obyczajów i wewnętrznej karności w wypełnianiu przyjętych zobowiązań.

\subsection{DYREKTOR}

Dyrektorem arcybractwa mógł być tylko kapłan. W parafiach ojców franciszkanów funkcję tę przeważnie pełnił przełożony wspólnoty zakonnej lub wyznaczony przez niego inny kapłan zakonny. W parafiach niezakonnych dyrektorem arcybractwa mógł być ksiądz mianowany przez generała braci mniejszych, za uprzednią zgodą biskupa miejsca. Generał miał prawo w ważnym przypadku, w porozumieniu z biskupem diecezjalnym, do odwołania dyrektora arcybractwa z jego funkcji (Can. 698. §3).

Dyrektor po objęciu funkcji w arcybractwie miał prawo do wpisywania kandydatów do księgi członkowskiej, przekazywania dyplomów bractwa, błogosławieństwa paska i wręczania go wpisanym. W powyższych czynnościach dyrektor nie mógł być zastępowany przez innych kałanów lub delegatów. Do niego należało kierowanie bractwem, dbanie nad przestrzeganiem karności, troska o rozwój i wzrost duchowy, a także głoszenie konferencji oraz zwoływanie zebrań i prowadzenie nabożeństw brackich ${ }^{49}$.

${ }^{47}$ Tamże, s. 118-119: podana została Formułka błogostawieństwa paska Ś.O.N. Franciszka.

${ }^{48}$ Arcybractwo Paska św. Franciszka, „Pochodnia Seraficka” 2 (1936), s. 58.

${ }^{49}$ Arcybractwo Paska św. Franciszka, "Wiadomości Tercjarskie" 28 (1936), s. 116, a także Arcybractwo Paska św. Franciszka, „Pochodnia Seraficka” 3 (1936), s. 91. 


\subsection{ODPUSTY}

Arcybractwo zostało obdarzone przez Stolicę Apostolską licznymi odpustami i łaskami ${ }^{50}$.

Warunki konieczne do uzyskania odpustów i łask:

1) wpisanie się do arcybractwa i noszenie paska,

2) spowiedź i komunia św.,

3) przy nawiedzeniu kościoła odmówienie 6 Ojcze nasz, 6 Zdrowaś Maryjo i 6 Chwata Ojcu.

W przypadku osób, które korzystały ze spowiedzi 2 razy w ciągu miesiąca lub przystępowały codziennie do komunii św. nie musiały dodatkowo się spowiadać, aby uzyskać odpust. Inne osoby mogły odprawić spowiedź 6 dni przed terminem odpustu, a komunię przyjąć w wigilię, wyznaczony dzień lub oktawę uroczystości odpustu.

Wyszczególniono odpusty zupełne i cząstkowe.

Odpusty zupełne można było uzyskać w następujących okolicznościach:

1) w dniu wstąpienia do arcybractwa i przyjęcia paska,

2) każdego roku w uroczyste święta brackie, przez nawiedzenie kościoła lub kaplicy, w których założone było arcybractwo i modlitwy w intencji papieża,

3) w godzinę śmierci za pobożne wymówienie Imienia Jezus po spowiedzi i Komunii św. lub po wzbudzeniu żalu doskonałego,

4) za uczestniczenie $w$ comiesięcznych procesjach brackich, po spowiedzi i przyjęciu Komunii św.,

5) przy nawiedzeniu kościoła brackiego od południa 1 sierpnia do północy 2 sierpnia.

Oprócz powyższych odpustów członkowie arcybractwa mogli uzyskać odpusty cząstkowe za wypełnienie następujących praktyk:

1) uczestniczenie $w$ miesięcznych procesjach brackich, bez spowiedzi i Komunii św. - 3 lata i 3 kawadragen,

2) uczestniczenie w oficjum o Matce Bożej, a także w każdym innym oficjum - $100 \mathrm{dni}$,

${ }^{50}$ Tamże, s. 91: „W ciągu wieków papieże szczodrze wyposażyli arcybractwo paska łaskami i odpustami. Uczynił to już jego założyciel Sykstus V, a potem Paweł V, Klemens X i Leon XIII. Odpusty te zebrane są w breve, Klemensa X "Dudum felicis" z r. 1673 (Bul. Rom VII, str. 225). Zatwierdziła je św. Kongregacja Odpustów i uznała, za autentyczne 1 czerwca 1866". 
3) za towarzyszenie kapłanowi z Najświętszym Sakramentem podczas drogi do chorego - 5 lat i 5 kwadragen,

4) po spowiedzi i komunii św. za nawiedzenie kościoła braci mniejszych franciszkanów i odmówieniu modlitwy w intencji papieża, w następujące uroczystości: św. Franciszka, św. Antoniego, św. Klary, Stygmatów św. Franciszka, św. Dydaka, św. Piotra z Alkantry, śś. Męczenników Zakonu, św. Elżbiety Węgierskiej - 7 lat i 7 kwadragen,

5) za udział w pogrzebach, pomoc biednym, wspomaganie zwaśnionych - 100 dni.

Inne przywileje:

1) w uroczystości św. Franciszka z Asyżu, św. Klary, św. Antoniego z Padwy, Stygmatów św. Franciszka zyskują specjalne uczestnictwo $\mathrm{w}$ łaskach i błogosławieństwach udzielonych zakonowi franciszkańskiemu za dobre uczynki oraz zasługi jego członków,

2) w uroczystość Niepokalanego Poczęcia N.M.P członkowie otrzymują specjalne błogosławieństwo papieskie ${ }^{51}$.

\subsection{ARCYBRACTWO PRZY KLASZTORACH FRANCISZKAŃSKICH W POLSCE}

Niezmiernie ważną pomocą $\mathrm{w}$ pracy duszpasterskiej Pierwszego Zakonu franciszkańskiego były liczne, prowadzone przez nich bractwa kościelne $^{52}$. Stowarzyszenia przenosiły w teren religijność franciszkańską. Bractwa prowadzone były przy wszystkich franciszkańskich kościołach klasztornych, a Konstytucje zakonne zobowiązywały przełożonych do szczególnej troski dotyczącej opieki i rozwoju ruchu brackiego.

Bractwo Paska św. Franciszka w Polsce powstało najwcześniej w Kalwarii Pacławskiej (1586) oraz w Krakowie (1587), później we Lwowie i w Gnieźnie. W Krakowie istniało ono przy bazylice św. Franciszka z Asyżu, a w 1586 roku agregowano je do Arcybractwa w Asyżu.

Pierwszy zakon franciszkański przechodził w swojej historii liczne przeobrażenia reorganizacyjne, aby odnieść się do okresu, w którym ar-

${ }^{51}$ Arcybractwo Paska św. Franciszka, „Pochodnia Seraficka” (1936), s. 91-92.

${ }^{52}$ K. Grudziński, Duszpasterstwo, w: Zakony św. Franciszka w Polsce w latach 1772-1970, Warszawa 1978, t. 3, red. J. Bar, s. 45-46. 
cybractwo paska św. Franciszka było najbardziej liczne, należy przybliżyć jakie obediencje znajdowały się w Polsce, czy też na jakim terenie Polski pod zaborami. W rodzinie Pierwszego Zakonu znajdowali się bernardyni (OFM), reformaci (OFM), franciszkanie (OFMConv) ${ }^{53}$ i kapucyni (OFMCap). W prowincjach Franciszkanów polskich (OFMConv) do czasu rozbiorów Polski istniało łącznie 57 bractw franciszkańskich (paska św. Franciszka, św. Antoniego), był to okres kiedy kończył się ich najbardziej dynamiczny rozwój. Następne lata po rozbiorze były okresem zamierania bractw.

Stan liczebny bractw Paska św. Franciszka działających przy kościołach Braci Mniejszych Konwentualnych w tym okresie wynosił łącznie 33 stowarzyszenia.

$\mathrm{W}$ prowincji polskiej istniały 23 bractwa $\mathrm{w}$ następujących miejscowościach: Bełchatowie, Chełmie, Chęcinach, Gnieźnie, Grabowie ${ }^{54}$, Inowrocławiu, Kaliszu ${ }^{55}$, Krakowie ${ }^{56}$, Lelowie, Łagiewnikach, Nieszawie ${ }^{57}$, Nowym Korczynie, Obornikach ${ }^{58}$, Piotrkowie ${ }^{59}$, Poznaniu, Pyzdrach, Radomsku, Radziejowie, Smardzewicach, Starym Sączu, Śremie ${ }^{60}$, Warce i Warszawie ${ }^{61}$.

W prowincji ruskiej istniało 10 bractw przy następujących klasztorach: w Gródku Jagiellońskim, Haliczu, Kamieńcu Podolskim, Kalwarii Pacławskiej, Krośnie, Krzemieńcu, Lwowie, Przemyślu, Sanoku i Szczebrzeszynie $^{62}$.

${ }^{53}$ D. Synowiec, Franciszkanie Polscy 1772-1970, w: Zakony św. Franciszka w Polsce w latach 1772-1970, Warszawa 1978, t. 2, red. J. Bar, s. 6: „Pod względem liczbowym stan w prowincjach polskich franciszkanów pod koniec XVIII w. przedstawiał się można powiedzieć pomyślnie: Zakon w Polsce zajmował piąte miejsce po bernardynach (2359), jezuitach (2330), dominikanach (2093), reformatach (1341). Liczył 1254 zakonników. Liczby tej nie osiągnięto już potem nigdy. Istniały trzy prowincje: 1) Polska pod wezwaniem św. Franciszka, 2) Ruska - pod patronatem św. Antoniego i 3) Litewska - pod opieką św. Kazimierza".

${ }^{54}$ B. Makowski, Brevis Descriptio Conventuum Provinciae Poloniae Ordinis Minorum Conventualium S.P. Francisci, 1762, s. 30: bractwo istniało w 1634 r.

55 B. Makowski, Brevis Descriptio Conventuum Provinciae Poloniae Ordinis Minorum Conventualium S.P. Francisci, 1762, s. 30: bractwo istniało w 1673 r.

${ }^{56}$ Tamże, s. 67.

57 Tamże: s. bractwo istniało w 1746.

${ }_{58}$ Tamże: s. bractwo istniało w 1722.

${ }^{59}$ Tamże, s. 50: bractwo istniało w $1664 \mathrm{r}$.

${ }^{60}$ Tamże, 45: bractwo istniało w $1720 \mathrm{r}$.

${ }^{61}$ D. Synowiec, Franciszkanie Polscy 1772-1970, s. 92, a także B. Makowski, Brevis Descriptio Conventuum Provinciae Poloniae Ordinis Minorum Conventualium S.P. Francisci, 1762, s. 173.

${ }^{62}$ Tamże, s. 93. 
Po kasacie bractw w Galicji próbowano niektóre ze stowarzyszeń reaktywować, niestety te starania się nie powiodły. Jedynie w Przemyślu, po kryjomu udało się wznowić bractwo Paska św. Franciszka (1794). Dopiero w drugiej połowie XIX wieku reaktywowano tylko kilka bractw, a mianowicie we Lwowie (1845-1865), Krakowie (od 1875) i Krośnie $(1854-1866)^{63}$.

\section{ZAKOŃCZENIE}

Pobożny zwyczaj noszenia paska franciszkańskiego przyciągał wiele ludzi, m.in. do grona takich osób należeli: św. Dominik Guzman (1170-1221) ${ }^{64}$, papież Grzegorz IX (1227-1241), św. Ludwik, biskup (1247-1297) i św. Brygida (1303-1373) $)^{65}$.

Poprzez praktyki pobożne członkowie arcybractwa wzrastali w drodze do zbawienia, których „tysiące, setki tysięcy na wzór Franciszka z miłości ku Ukrzyżowanemu porzuca wszystko i, przepasują biodra sznurem, podąża za świetlaną postacią drogowskazu... ku wyżynom"66.

Popularność i różnorodność bractw religijnych wpływała na wzrastającą liczbę dzieł dobroczynnych. Miały też udział w zdobieniu oraz w budowie kościołów i kaplic. Pozostawiły one po sobie również liczne ślady w literaturze i sztuce.

Streszczenie. Człowiek wierzący dąży do zbawienia, które można osiągnąć, idąc różnymi drogami. Jedną z nich było zrzeszanie się w bractwach kościelnych pomocnych w osiągnięciu tego celu. Do bractw religijnych przyjmowano na zasadzie dobrowolności, nie określano stanu posiadania, pochodzenia, czy też innych warunków społeczno-ekonomicznych. Jedynym kryterium była wola osiągnięcia łaski nieba, która tworzyła więź wspólnoty brackiej wyrażanej poprzez braterską modlitwę, a także troskę o ubogich. Ponadto opiekowano się powierzonymi kaplicami, ołtarzami i feretronami (obrazami), co miało wpływ na aktywność ludzi świeckich w parafiach.

Postać św. Franciszka z Asyżu inspirowała ludzi różnych epok, kultur i religii. Idee Franciszkowe realizowały osoby konsekrowane i świeckie, a także

${ }^{63}$ Tamże, s. 95.

${ }^{64}$ Arcybractwo Paska św. Franciszka, „Pochodnia Seraficka” 7 (1935), s. 220: „Historja wspomina, że już św. Dominik, wielki założyciel potężnego zakonu kaznodziejskiego, przyjął z rąk św. Franciszka taki powróz i opasawszy się nim, nosił go do śmierci".

${ }_{65}$ Arcybractwo Paska św. Franciszka, „Wiadomości Tercjarskie” 28 (1936), s. 108.

${ }^{66}$ Arcybractwo Paska św. Franciszka, „Wiadomości Tercjarskie” 28 (1936), s. 108. 
członkowie bractw opierających się na duchowości franciszkańskiej, wśród nich Arcybractwo Paska św. Franciszka.

Arcybractwo Paska zostało założone w bazylice asyskiej i zatwierdzone przez papieża Sykstusa V (1585-1590). W Polsce arcybractwo rozpowszechniało już w drugiej połowie XVI wieku.

Popularność i różnorodność bractw religijnych wpływała na wzrastającą liczbę dzieł dobroczynnych. Miały też udział w zdobieniu oraz w budowie kościołów i kaplic. Pozostawiły one po sobie również liczne ślady w literaturze i sztuce.

Słowa kluczowe: Sykstus V; arcybractwo; bractwo; św. Franciszek z Asyżu; franciszkanie; odpusty; przywileje; klasztor; stowarzyszenie; zbawienie.

Abstract. Archconfraternity of Paska Saint Francis of Assisi in Poland over the centuries. The believers seek salvation which can be achieved in many ways. One of them was joining a church brotherhood. Whoever willing was accepted to the church brotherhood, there were no restrictions about possessions, origins or socio-economical conditions. The only requirement was the will to reach the grace of heaven, which created the bond of brotherhood in their fraternal prayers and the care about the poor. Beside that, brothers took care of the chapels, alters and feretories, which all had a great influence on the lay people to be more active in the parishes.

The person of Saint Francis of Assisi inspired the great people of different epochs, cultures and religions. Francis' ideas were realized by both consecrated and secular people, as well as by the members of the fraternities, among which was archconfraternity of Paska Saint Francis of Assisi.

Archconfraternity of Paska was founded in the basilica (Assisi) and confirmed by the Pope Sixtus V (1585-1590). In Poland the archconfraternity well spread in the second half of XVI century.

The popularity and variety of brotherhoods had a great influence on the growing number of charity works. It contributed to adorning and building the churches and chapels. They left marks in literature and art.

Keywords: Sixtus V; archconfraternity; brotherhood; Saint Francis of Assisi; franciscans; indulgences; privileges; monastery; association; salvation. 